Tinjauan Pustaka

\title{
PENGGUNAAN ANTIKOAGULAN PADA PENYAKIT GINJAL KRONIK
}

Wiza Erlanda ${ }^{1}$, Yerizal Karani²

\begin{abstract}
Abstrak
Antikoagulan adalah terapi utama untuk pencegahan dan pengobatan akut dan jangka panjang dari berbagai macam tipe penyakit tromboemboli. Dalam klinis, penggunaan antikoagulan harus diperhatikan antara manfaat dan risiko yang ditimbulkannya, antara pencegahan kejadian tromboemboli dan risiko perdarahan terutama pada pasien dengan kondisi khusus seperti penyakit ginjal kronik (PGK). Sebagaimana kita ketahui pasien dengan penyakit ginjal kronik mengalami abnormalitas pada kaskade koagulasi. Hal ini mungkin menjelaskan mengapa pada pasien PGK dapat terjadi 2 kejadian hemostatis yang berlawanan: perdarahan dan kecenderungan trombosis. Begitu juga dalam penggunaan agen antikoagulan dimana penyakit ginjal berhubungan dengan penurunan stabilitas antikoagulan, yang ditandai dengan penurunan yang signifikan pada TTR (time in therapeutic range) obat. Banyak antikoagulan yang diekskresikan melalui ginjal, sehingga perlu penyesuaian jenis dan dosis antikoagulan pada pasien dengan PGK untuk menghindari risiko terakumulasinya obat yang cenderung menimbulkan perdarahan.
\end{abstract}

Kata kunci: Antikoagulan, Penyakit Ginjal Kronik

\begin{abstract}
Anticoagulant are the mainstay of therapy for acute and long-term prevention and treatment of thromboembolic disorders. In clinical use of anticoagulants should be noted between the benefits and the risks this poses, between the prevention of thromboembolic events and the risk of bleeding, especially in patients with specific conditions such as chronic kidney disease (CKD). As we know, Patients with CKD may present with abnormalities in the enzymatic coagulation cascade. This may explain why patients with CKD may experience 2 opposite hemostatic events: bleeding diathesis and thrombotic tendencies. So also in the use of anticoagulant agents which kidney disease associated with reduced anticoagulant stability, which is characterized by a significant decrease in TTR (time in therapeutic range) drugs. Many anticoagulants are excreted through the kidneys, so that the necessary adjustments to the type and dose of anticoagulants in patients with CKD to avoid the risk of drug accumulation which tends to cause bleeding.
\end{abstract}

Keywords: Anticoagulant, Chronic Kidney Disease

\author{
Affiliasi penulis : 1. PPDS IImu Penyakit Jantung dan Pembuluh \\ Darah 2. Bagian Kardiologi dan Kedokteran Vaskular Fakultas \\ Kedokteran UNAND / RSUP Dr. M. Djamil \\ Korespondensi : Jalan Perintis Kemerdekaan Padang \\ kardiologiunand@yahoo.com Telp: 075136494
}

\section{PENDAHULUAN}

Antikoagulan adalah terapi utama untuk pencegahan dan pengobatan akut dan jangka panjang dari berbagai macam tipe penyakit tromboemboli. ${ }^{1,2}$ Atrial fibrilasi merupakan salah satu penyakit yang banyak menggunakan antikoagulan untuk pencegahan stroke tromboemboli. Selain itu, antikoagulan juga banyak digunakan pada pasien dengan sindrom koroner akut, pencegahan dan terapi tromboemboli vena termasuk trombosis vena dalam dan emboli paru. ${ }^{1,2}$ Antagonis vitamin $\mathrm{K}$ (warfarin), heparin (unfractionated heparin, low molecular-weight heparin, direct thrombin inhibitor (argatroban dan dabigatran), dan penghambat factor Xa (apixaban, fondaparinux, dan rivaroxaban) merupakan antikoagulan yang digunakan untuk terapi dan pencegahan utama pada penyakit tersebut. Dalam klinis, penggunaan antikoagulan harus diperhatikan antara manfaat dan risiko yang ditimbulkannya, antara pencegahan kejadian tromboemboli dan risiko perdarahan terutama pada pasien dengan kondisi khusus seperti penyakit ginjal kronik (PGK). ${ }^{3-4}$

Rasio risiko dan manfaat dengan terapi antitrombotik harus dipertimbangkan pada pasien PGK, karena memiliki risiko perdarahan yang tinggi. Selain itu pasien PGK yang mendapatkan lebih sedikit obat terbukti lebih baik. 5,6

Oleh karena itu, dalam tinjauan klinis ini akan dibahas lebih dalam mengenai penggunaan antikoagulan yang tepat pada pasien dengan penyakit ginjal kronik.

\section{PEMBAHASAN}

\section{PENYAKIT GINJAL KRONIK}

Menurut Kidney Disease: Improving Global Outcomes (KDIGO) tahun 2013, PGK adalah kelainan struktural atau fungsi yang terjadi lebih dari 3 bulan dan mempunyai implikasi terhadap kesehatan serta diklasifikasikan berdasarkan penyebab, laju filtrasi 
glomerulus (LFG) dan albuminuria. $^{7}$ Tabel 1 menjelaskan klasifikasi PGK berdasarkan laju filtrasi glomerulus

Tabel 1. Stadium penyakit ginjal kronik berdasarkan $\mathrm{LFG}^{7}$

\begin{tabular}{lll}
\hline St & $\begin{array}{l}\text { Nilai LFG } \\
\left(\mathrm{ml} / \text { menit/1.73m² }^{2}\right)\end{array}$ & Keterangan \\
\hline 1 & $\geq 90$ & LFG normal atau lebih tinggi \\
2 & $60-89$ & LFG menurun ringan \\
$3 a$ & $45-59$ & $\begin{array}{l}\text { LFG menurun ringan } \\
\text { sampai sedang }\end{array}$ \\
$3 b$ & $30-44$ & LFG menurun sedang \\
4 & $15-29$ & sampai berat \\
5 & $<15$ & LFG menurun berat \\
& & Gagal Ginjal
\end{tabular}

\section{FISIOLOGI KOAGULASI}

Kaskade koagulasi terbagi atas dua jalur yaitu jalur intrinsik (aktivasi kontak) dan jalur ekstrinsik (faktor jaringan). Awalnya kaskade tersebut dipicu oleh pelepasan faktor jaringan akibat trauma jaringan atau kerusakan vaskular. Faktor-faktor yang telah diaktifkan akan mengkatalisis reaksi berikutnya dalam kaskade.
Faktor jaringan membentuk kompleks dengan faktor VIla dengan adanya kalsium dan memecah pembekuan faktor $\mathrm{X}$ dan IX untuk bentuk aktif mereka (faktor Xa dan IXa). Kompleks protrombinase kemudian terikat pada membran fosfolipid dan memecah protrombin (faktor II) untuk faktor Ila (trombin). Trombin memainkan peran penting dengan memicu konversi fibrinogen larut ke fibrin monomer yang tidak larut, yang berfungsi sebagai dasar untuk pembentukan trombus. Trombin adalah salah satu aktivator hemostasis yang paling poten primer (dimediasi platelet) dan sekunder (dimediasi factor pembekuan). Trombin juga poten membentuk bekuan fibrin oleh polimerisasi, aktivasi reseptor platelet, aktivasi endotel, dan aktivasi factors $\mathrm{V}, \mathrm{VIII}, \mathrm{XI}$, dan XIII. (Gambar.1).8,9,10

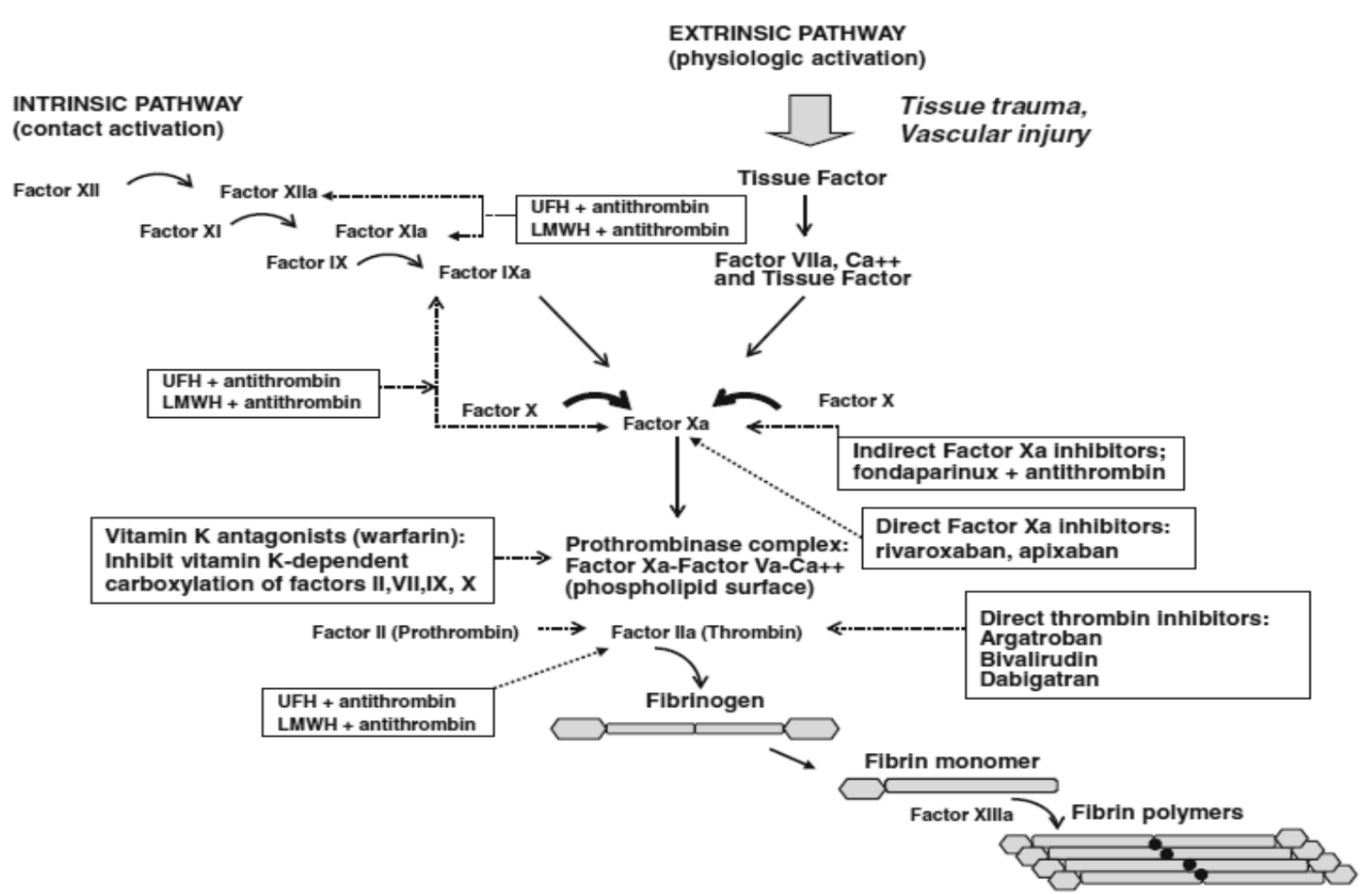

Gambar 1. Kaskade koagulasi dan peranan antikoagulan ${ }^{8}$ 


\section{STABILITAS ANTIKOAGULAN PADA PENYAKIT GINJAL KRONIK}

Pasien dengan penyakit ginjal kronik mengalami abnormalitas pada kaskade koagulasi. Hal ini mungkin menjelaskan mengapa pada pasien PGK dapat terjadi 2 kejadian hemostatis yang berlawanan: perdarahan dan kecenderungan trombosis. ${ }^{1,11-16}$

Penyakit ginjal berhubungan dengan penurunan stabilitas antikoagulan, yang ditandai dengan penurunan yang signifikan pada TTR (time in therapeutic range) obat. Penyakit ginjal kronik mungkin berefek pada farmakokinetik antikoagulan melalui berbagai parameter yaitu terjadinya peningkatan bioavailabilitas obat, peningkatan distribusi, waktu paruh yang memanjang, pemanjangan waktu untuk mencapai konsentrasi maksimum obat, dan berkurangnya ekskresi obat. Penurunan ekskresi melalui ginjal dapat mencapai $50 \%$, yang menyebabkan penumpukan obat hampir pada $2 / 3$ pasien..$^{1,4,13}$

\section{PENGGUNAAN ANTIKOAGULAN PADA PENYAKIT GINJAL KRONIK}

INDIRECT THROMBIN INHIBITORS

Unfractionated Heparin (UFH)

Meskipun telah banyak pengalaman penggunaan UFH dalam praktek sehari-hari, sedikit bukti yang tersedia untuk mengkonfirmasi keamanan UFH dalam kelompok berisiko tinggi ini. Sebuah analisis post-hoc dari percobaan acak besar terkontrol, ESSENCE dan TIMI 11b, menyelidiki keamanan enoxaparin dan UFH untuk pengobatan ACS pada pasien dengan LFG $<30 \mathrm{~mL} /$ menit. Analisis menunjukkan bahwa risiko perdarahan pada pasien dengan PGK (LFG <30 mL / menit) lebih besar dari pada pasien dengan LFG $>30 \mathrm{~mL} /$ menit terlepas dari antikoagulan yang digunakan. ${ }^{2,17}$

Singkatnya, keuntungan dari menggunakan UFH pada pasien dengan penyakit ginjal berat tidak karena risiko perdarahan yang lebih rendah, tetapi lebih karena kemudahan di mana setiap episode perdarahan dapat dikoreksi dengan keuntungan waktu paruh terapi UFH yang pendek dan perbaikan sempurna dengan protamine. , $2,17,18^{2}$
Low Molecular Weight Heparin (LMWH)

Tidak semua LMWH dibuat sama. LMWH yang rutin digunakan di Inggris adalah enoxaparin, dalteparin dan tinzaparin, dengan masing-masing memiliki jadwal pemberian dosis dan indikasi yang berbeda untuk pengobatan ACS dan TE vena. ${ }^{2,12}$

LMWH dengan berat molekul yang lebih rendah sangat tergantung pada bersihan ginjal dan karena itu mungkin terakumulasi pada pasien dengan disfungsi ginjal dan akan lebih terasa dengan LMWH lebih kecil. $2,8,18$

Karena akumulasi yang terjadi dari semua LMWH pada disfungsi ginjal berat, pasien dengan disfungsi ginjal telah dikeluarkan dari sebagian besar percobaan yang dilakukan dengan LMWH. Tanpa hasil ini dan kurangnya data keamanan dan kemanjuran, diperlukan kehati-hatian ketika pemberian dosis LWMHs pada pasien dengan gangguan ginjal. Penurunan dosis dan pemantauan anti-faktor $\mathrm{Xa}$ umumnya disarankan.2,18

a. Anti-Factor Xa Inhibitors (Fondaparinux)

Fondaparinux merupakan antikoagulan dimana terutama diekskresi sebagai obat utuh oleh ginjal pada pasien dengan fungsi ginjal yang normal. Sebaliknya, ekskresi fondaparinux menurun dengan peningkatan gangguan ginjal. ${ }^{19}$

Tidak ada pengurangan dosis diperlukan untuk pasien dengan PGK stadium 2 sampai 3, sedangkan fondaparinux harus dihindari pada pasien PGK stadium 4.2,19

b. Direct Thrombin Inhibitors (DTIs)

Direct Thrombin Inhibitors memberikan efek antitrombotik secara langsung, selektif, dan reversibel mengikat pada tempat trombin aktif. Hirudin analog yaitu desirudin dan bivalirudin, dan argatroban merupakan DTIs yang telah disetujui. ${ }^{1,2,8}$

Bivalirudin dibersihkan dari plasma melalui kombinasi mekanisme ginjal dan enzimatik. Karena eliminasi obat berhubungan linier dengan LFG, dosis infus bivalirudin mungkin perlu dikurangi pada pasien dengan PGK berat. Secara khusus, penyesuaian dosis $1,75 \mathrm{ke} 1,0 \mathrm{mg}$ atau $0,25 / \mathrm{kg} / \mathrm{h}$ harus dipertimbangkan pada pasien dengan stadium 4 atau 5 CKD, masingmasing. ${ }^{17,18}$

Penggunaan antikoagulan parenteral pada

PGK dapat dilihat pada tabel 2. 
Tabel 2. Dosis Antikoagulan Parenteral pada Penyakit Ginjal Kronik ${ }^{17}$

\begin{tabular}{|c|c|c|}
\hline Agent & Dosing in CKD & Comment \\
\hline $\begin{array}{l}\text { Unfractionated } \\
\text { heparin }\end{array}$ & No adjustment necessary & $\begin{array}{l}\text { Low antithrombin activity may } \\
\text { affect dosing requirements. }\end{array}$ \\
\hline Dalteparin & No adjustment for $\mathrm{CrCl} \geq 20 \mathrm{~mL} / \mathrm{min}$ & $\begin{array}{l}\text { Dosing adjustment for } \mathrm{CrCl} \\
<20 \mathrm{~mL} / \mathrm{min} \text { unclear. }\end{array}$ \\
\hline \multirow[t]{2}{*}{ Enoxaparin } & $\mathrm{CrCl}>60 \mathrm{~mL} / \mathrm{min}:$ no dose modification & Dosing adjustment for $\mathrm{CrCl}$ \\
\hline & $\mathrm{CrCl} 30-60 \mathrm{~mL} / \mathrm{min}: 25 \%$ dose reduction & $<20 \mathrm{~mL} / \mathrm{min}$ unclear. \\
\hline Tinzaparin & $\begin{array}{l}\mathrm{CrCl} 20-30 \mathrm{~mL} / \mathrm{min}: 50 \% \text { dose reduction } \\
\text { No adjustment for } \mathrm{CrCl} \geq 20 \mathrm{~mL} / \mathrm{min}\end{array}$ & $\begin{array}{l}\text { Adjustment for } \mathrm{CrCl} \\
<20 \mathrm{~mL} / \mathrm{min} \text { unclear. }\end{array}$ \\
\hline Fondaparinux & Contraindicated in $\mathrm{CrCl}<30 \mathrm{~mL} / \mathrm{min}$. & $\begin{array}{l}\text { Dosing adjustments for renal } \\
\text { function are unclear. }\end{array}$ \\
\hline Argatroban & $\begin{array}{l}\text { Renal dysfunction dose adjustment unclear. } \\
\text { Fraction of extraco rporeal clearance not clinically } \\
\text { significant. }\end{array}$ & $\begin{array}{l}\text { Dose reduction of } 0.1-0.6 \mu \mathrm{g} / \mathrm{kg} / \\
\mathrm{min} \text { per } 30 \mathrm{~mL} / \mathrm{min} \text { decrease } \\
\text { in } \mathrm{CrCl} \text { has been suggested. }\end{array}$ \\
\hline \multirow[t]{5}{*}{ Bivalirudin } & $\begin{array}{l}\text { Eliminated enzymatically and renally; however, } \\
\text { clearance relationship exists between } \mathrm{CrCl} \text { and } \\
\text { dose requirements. }\end{array}$ & $\begin{array}{l}\text { Substantially removed during } \\
\text { HD. Higher doses a re used } \\
\text { during cardiac interventional }\end{array}$ \\
\hline & HIT and VTE dosing: & procedures with adjustment \\
\hline & $\mathrm{CrCl}>60 \mathrm{~mL} / \mathrm{min}: 0.15 \mathrm{mg} / \mathrm{kg} / \mathrm{h}$ & for renal dysfunction \\
\hline & $\mathrm{CrCl} 30-60 \mathrm{~mL} / \mathrm{min}: 0.08-0.1 \mathrm{mg} / \mathrm{kg} / \mathrm{h}$ & necessary. \\
\hline & $\mathrm{CrCl}<30 \mathrm{~mL} / \mathrm{min}$ or hemodialysis: $0.03-0.05 \mathrm{mg} / \mathrm{kg} / \mathrm{h}$ & \\
\hline \multirow[t]{6}{*}{ Lepirudin } & Dose $(\mathrm{mg} / \mathrm{kg} / \mathrm{h})$ & Doses as low as $0.005 \mathrm{mg} / \mathrm{kg} / \mathrm{h}$ \\
\hline & $0.1-0.15$ & have been used in renal \\
\hline & $45-60$ & failure requiring \\
\hline & $30-44$ & hemodialysis. \\
\hline & 0.0225 & \\
\hline & 0.02 or less & \\
\hline
\end{tabular}

c. Antikoagulan Oral: Vitamin K Antagonis

Antagonis vitamin $\mathrm{K}$ (VKAs) menghasilkan efek antikoagulan dengan menghambat vitamin $\mathrm{K}$ epoxy reduktase, yang diperlukan untuk konversi vitamin $\mathrm{K}$ menjadi vitamin $\mathrm{KH} 2$ aktif. Protein bergantung vitamin $\mathrm{K}$ seperti faktor pembekuan II, VII, IX, dan X membutuhkan c-karboksilasi oleh vitamin $\mathrm{KH} 2$ untuk aktivitas biologis. $3,18,19,20$

Warfarin dan acenocoumarol (vitamin $\mathrm{K}$ antagonis) tidak diekskresi terutama melalui ginjal. Meskipun demikian, pemberian dosis yang hati-hati dan monitoring INR lebih sering telah direkomendasikan pada pasien dengan PGK stadium 3 ke bawah karena risiko yang lebih tinggi untuk komplikasi perdarahan. 12,20,21

Pada pasien PGK ada beberapa faktor spesifik ginjal yang harus diingat dengan penggunaan warfarin yaitu :

(i) Penggunaan dosis rendah: Limdi dkk. telah menunjukkan pasien dengan disfungsi ginjal berat memerlukan dosis harian warfarin secara signifikan yang lebih rendah untuk mencapai INR terapeutik dibandingkan dengan kontrol fungsi ginjal normal. (ii) INR labil: pasien PGK menghabiskan waktu yang lebih lama di luar target INR dan beresiko tinggi supraterapeutik antikoagulasi (INR> 4).

(iii) Dalam sebuah penelitian baru-baru ini, penggunaan warfarin dikaitkan dengan risiko lebih rendah 1 tahun untuk kematian, infark miokard dan stroke iskemik tanpa risiko lebih tinggi perdarahan. Asosiasi ini tidak terkait dengan tingkat keparahan PGK.

(iv) Warfarin terkait nefropati: ini adalah kejadian dimana terjadi peningkatan serum kreatinin $\geq 0.3$ $\mathrm{mg} / \mathrm{dL}$ dalam waktu 1 minggu dan pembacaan INR dari $\geq 3,0$ yang tidak bisa dijelaskan penyebabnya. Hal ini diduga disebabkan oleh perdarahan glomerulus dan obstruksi tubular oleh sel darah merah.

(v) Meskipun risiko tinggi perdarahan dan kurangnya bukti pada populasi ini, warfarin masih direkomendasikan untuk pengobatan VTE dan fibrilasi atrium (AF). Sebuah pendekatan start low go-slow terhadap dosis warfarin disarankan untuk menghindari overantikoagulasi pada pasien dengan disfungsi ginjal berat. ${ }^{2,12,22,23}$

Berikut adalah algoritma dalam penggunaan warfarin pada pasien atrial fibrilasi dengan PGK : 


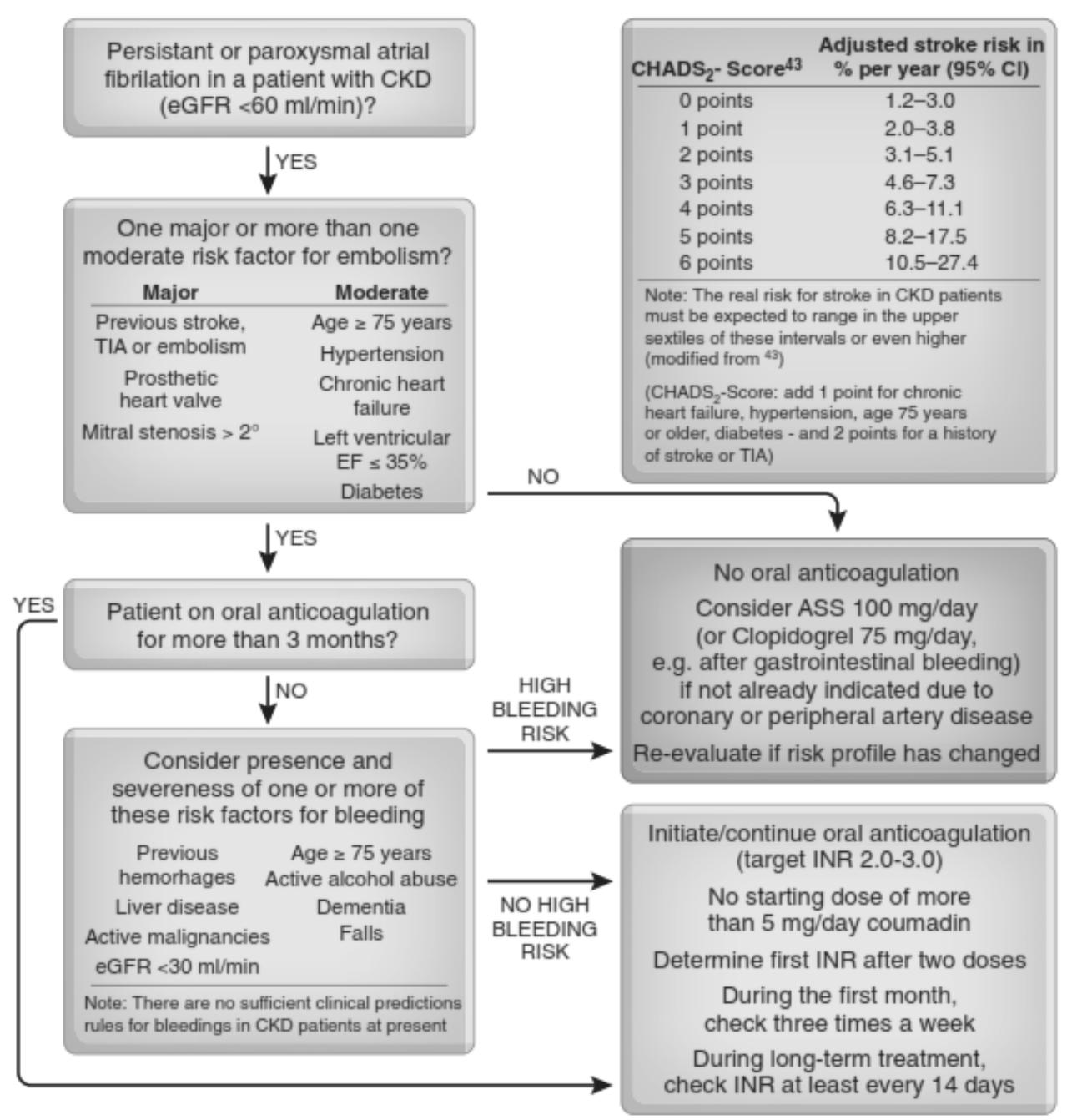

Gambar 2. Algoritma pemberian warfarin pada pasien fibrilasi atrium dengan PGK ${ }^{12}$

\section{d. New Oral Anticoagulant (NOAC)}

Dalam beberapa tahun terakhir, terdapat antikoagulan oral baru yang digunakan untuk pencegahan dan pengobatan VTE serta pencegahan stroke pada pasien AF. Keuntungan utama dari antikoagulan oral baru ini adalah efek terapeutik yang dapat diprediksi dan tidak perlu monitoring terapi. Salah satu yang masih menjadi isu penting adalah bersihan ginjal yang harus diperhatikan dalam pemberian antikoagulan ini. Diperlukan pengitungan bersihan ginjal (LFG) untuk monitoring penggunaan antikoagulan ini. 1,2,18,19

Dabigatran etexilate mesylate adalah prodrug. Dabigatran dieliminasi melalui filtrasi ginjal sampai dengan $80 \%$ dari dosis diekskresikan dalam urin. Berarti eliminasi dabigatran memanjang pada kondisi disfungsi ginjal berat. (gambar 3$)^{1}$

Tidak ada obat penawar yang tersedia untuk membalikkan atau melemahkan efek antikoagulan dabigatran ini. Untuk alasan ini, FDA menyetujui dosis $75 \mathrm{mg}$ dua kali sehari untuk pasien dengan PGK stadium 4 (LFG 15-30 mL / menit).1,12,24

Guideline tidak merekomendasikan penggunaan rivaroxaban dan dabigatran pada pasien dengan bersihan kreatinin diperkirakan kurang dari 15 $\mathrm{mL} /$ menit. Begitu juga dengan apixaban dimana walaupun lebih superior dibandingkan warfarin, pada PGK stadium >3 didapatkan risiko yang lebih tinggi terjadi perdarahan mayor dibandingkan warfarin. 1,2,23 


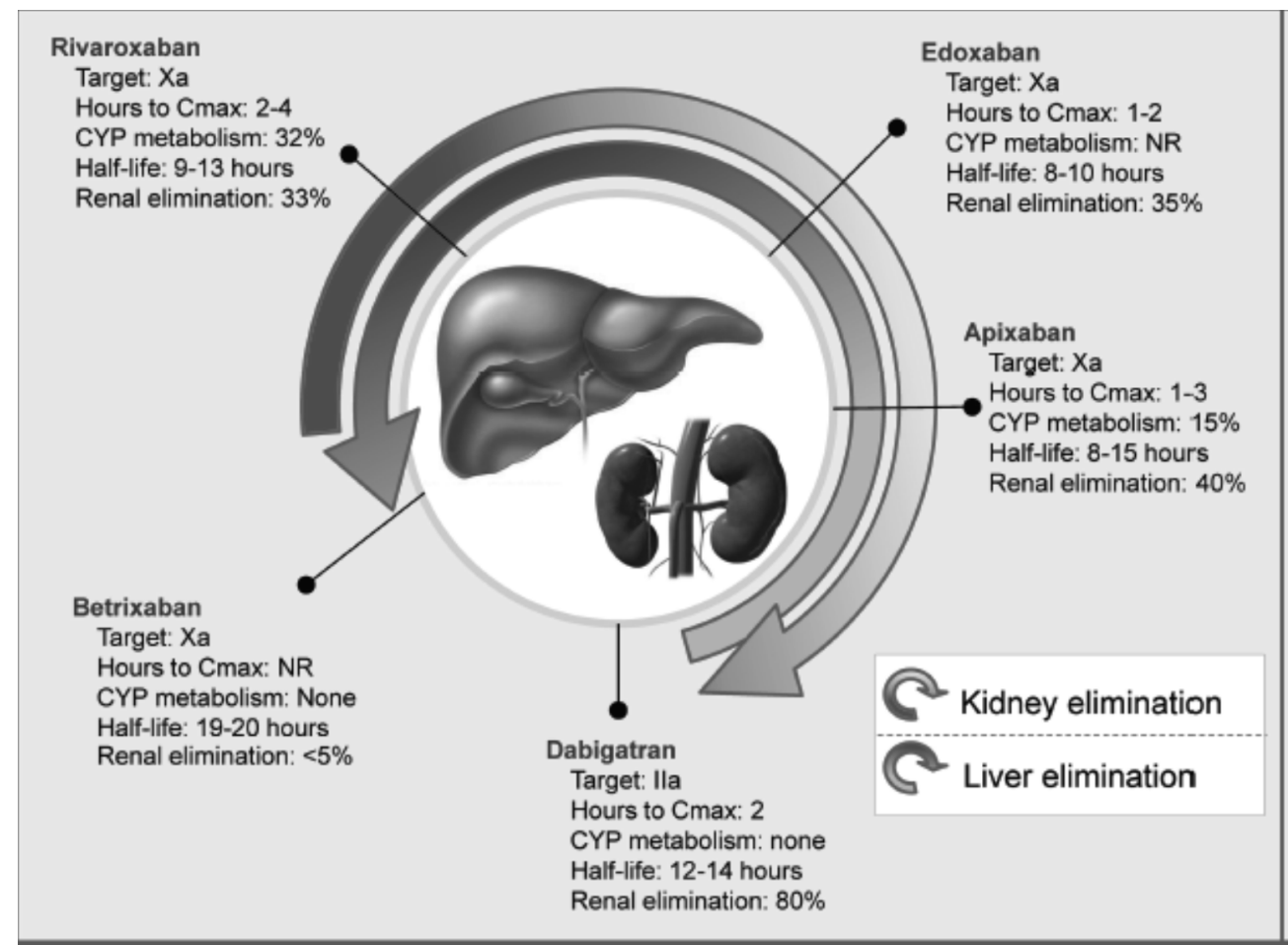

Gambar 3. Sifat Farmakologi New Anticoagulant ${ }^{1}$

Karena tidak ada obat penawar saat ini ada untuk perdarahan aktif yang terkait dengan antikoagulan oral baru ini dan juga perpanjangan waktu paruh terapeutik pada pasien PGK stadium 4/5, agen ini harus digunakan dengan hati-hati pada populasi tersebut.2,10,24

Beberapa hal yang harus diperhatikan dalam penggunaan antikoagulan ini, yaitu:

(i) Pasien harus melakukan tes fungsi ginjal awal sebelum memulai agen terapi ini. Fungsi ginjal dapat menurun saat pengobatan maka memantau setiap tahun atau lebih sering pada pasien berisiko tinggi.

(ii) Penyakit akut sering secara sementara mempengaruhi fungsi ginjal (infeksi, gagal jantung akut, dII), dan karena itu harus dilakukan evaluasi ulang. Perawatan harus diambil ketika meresepkan obat lain yang mungkin bersifat nefrotoksik dalam situasi seperti itu.

(iii) Ringkasan karakteristik produk untuk dabigatran merekomendasikan bahwa agen ini dikontraindikasi pada pasien dengan LFG $<30$ $\mathrm{mL} / \mathrm{menit}$. Pasien dengan risiko tinggi perdarahan dan semua pasien dari $\geq 80$ tahun harus diberikan dosis yang lebih rendah $(110 \mathrm{mg}$ dua kali sehari) dan dosis dikurangi ini dianjurkan untuk semua. Lisensi US menyarankan dosis yang dikurangi (75 mg dua kali sehari) untuk pasien dengan LFG $15-30 \mathrm{~mL} /$ menit tapi ini tetap merupakan indikasi off-label di Inggris pada saat cetak.

(iv) Rivaroxaban dikontraindikasikan pada pasien dengan LFG dari $<15 \mathrm{~mL}$ / menit dan dosis harus dikurangi 15-20 mg sehari pada mereka dengan LFG dari 15-49 mL / menit.

(v) Pada pasien dengan LFG 15-29 $\mathrm{mL} / \mathrm{menit}$, apixaban harus diberikan dengan dosis $2,5 \mathrm{mg}$ dua kali sehari. Beberapa literatur mengatakan untuk tidak diberikan.

(vi) Terapi antikoagulan oral yang baru harus dihindari dan antagonis vitamin $\mathrm{K}$ mungkin menjadi alternatif terapi yang lebih cocok untuk saat ini pada pasien AF yang dihemodialisis. Sementara terapeutik warfarin yang tetap tak terduga dan bukan tanpa komplikasi, tetap harus diperhatikan dan ditempatkan pada grup dengan risiko tinggi perdarahan. ${ }^{2,24,25}$

Untuk dosis pemberian NOAC berdasarkan indikasi dan fungsi ginjal dapat dilihat pada table 3 . 
17. Garcia DA, Baglin TP, Weitz JI. Parenteral anticoagulants. Chest. 2012; 141(Suppl 2): e24S-e43S

18. Blostein M, Kerzner R. Practice Guidelines for Anticoagulation Management, $3^{\text {rd }}$ ed. Jewish General Hospital. 2012; 3-33

19. Holbrook A, Schulman S, Witt DM, Vandvic PU, Fish J, Kovacs MJ, et al. Evidence-Based Management of Anticoagulant Therapy. Chest. 2012; 141(2 Supp); e152 S-e184 S

20. Kleinow ME, Garwood CL, Clemente JL, Whittaker P. Effect of Chronic Kidney Disease on Warfarin Management in Pharmacist. Journal of Managed Care Pharmacy. 2011; 17(7); 523-529

21. Keeling D, Baglin T, Tant C, Watson H, Perry D, Baglin $C$, et al. Guidelines on Oral Anticoagulation with Warfarin- $4^{\text {th }}$ edition. British Journal of Haematology. 2011; 1-14

22. Banerjee A, Faucher L, Vourc'h $P$, Andres $C R$, Taillandier S, Halimi JM, et al. Renal Impairment and Ischemic Stroke Risk Assessment in Patients with Atrial Fibrillation. Journal of American College of Cardiology. 2013; 61(20); 2079-2087

23. Heine $\mathrm{GH}$, Brandenburg V. Anticoagulation, atrial fibrillation, and chronic kidney disease-who side are you on. Kidney International. 2017; 91:778780

24. Vega LB, de Fransisco A, da Silvia JB, Espinoza LG, Fresnedo GF. New oral anticoagulant in patient with chronic kidney disease. Nefrologia. 2017;37(3);241-252

25. Jain N, Reilly RF. Clinical Pharmacology of Oral Anticoagulant in Patients with Kidney Disease. Clin J Am Soc Nephrol. 2018;14;1-10 